\title{
Doctors for the Environment Australia: achievments and lessons learned
}

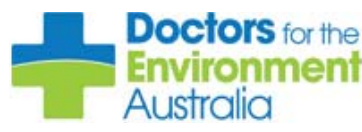

\section{Political ideology has proved to be the greatest obstacle to DEA's ability to reduce the health hazards of climate change}

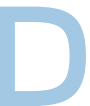

octors for the Environment Australia (DEA), created in 2002, aimed "to utilise the skills of members of the medical profession to address the ill health resulting from damage to the natural environment at local, national and global levels".1 This agenda was overwhelming, and with humanity's astonishing failure to stop the rise of greenhouse gas emissions and the gathering pace of climate change, DEA has focused on the medical threats of climate change. As a medical organisation, DEA was a frontrunner in its forthright recognition of this problem, which the World Health Organization now regards as the defining health issue of our time. DEA maintains that the established medical colleges and organisations need to speak out more strongly about the health hazards of climate change.

Since our inception we have had committed assistance from many distinguished medical and scientific colleagues. The late Tony McMichael was a founding member and tireless supporter of DEA with his advice and valuable long-term involvement with students and politicians. He helped us with policy and landmark publications. DEA and global public health owe him a huge debt. ${ }^{2}$

In 2009, the DEA made a policy decision to advocate and educate on the health effects of using fossil fuels as well as climate change. This led to our work on the health effects of coal combustion, which is actually an expensive form of power generation. ${ }^{3,4}$ The DEA promotes renewable energy as a replacement for coal, and educates about the potential harms of unconventional gas exploration and production.

In 2010, the DEA began to encourage its membership to divest from fossil fuel industries by pressuring the "big four" banks to withdraw from financing fossil fuel expansion, thus presaging the current and gathering momentum to encourage divestment from the fossil fuel industries.

In recent times DEA's advocacy has included providing advice to governments and oppositions on the health impacts of coal seam gas, shale gas and coal, campaigning to save the Tarkine region in Tasmania from further mining developments, challenging the Victorian Environmental Protection Agency for approving a new coal-fired power plant and contributing to the development of the Climate Commission's report, The critical decade: climate change and health. ${ }^{5}$

Of the problems faced when the DEA was formed, the most underestimated was political ideology as an impediment to progress. ${ }^{6,7}$ In Australia the health aspects of climate change are decided in an unequal contest between public health and an alliance of
David J C Shearman MBChB, PhD, FRACP Emeritus Professor, ${ }^{1}$ and Founder and Honorary Secretary ${ }^{2}$

William M Castleden MS, FRCS, FRACS Founding Chairman, ${ }^{2}$ and Emeritus Consultant ${ }^{3}$

1 Department of Medicine, University of Adelaide, Adelaide, SA.

2 Doctors for the Environment Australia, Adelaide, SA.

3 Department of Vascular Surgery, Fremantle Hospital, Fremantle, WA.

mountlofty@ ozemail.com.au

doi: 10.5694/mjal4.01352

In Australia the health aspects of climate change are decided in an unequal contest between public health and an alliance of government, industry and much of the media government, industry and much of the media. Health impact assessments are invisible in the crusade to push fossil fuel development and cut green tape. The scientific aspects of climate change are dismissed as "crap". The conservative mind has become fixated on the perceived threats to economic growth imposed by the environmental movement. The intent of DEA has been to present global environmental change as a vital health concern and an increasing cost to our economic futures. In this regard, the Australian Government's action on the carbon tax and the renewable energy target can be regarded as a threat to the vital public health need to reduce greenhouse gas emissions.

The DEA website (http://dea.org.au) provides details of our submissions, policies and activism. However, our greatest achievement has surely been involving medical students as full members who contribute to all levels of the decision making and to the activities of state committees, visits to ministers and members, letter writing and presentations to parliaments. More than 300 students attended this year's DEA conference. This promises a wave of informed activism and medical knowledge that is essential for action on public health over the crucial next 20 years.

Although most DEA members are practising doctors, all sections of the medical community are represented as reflected in our promotional video. ${ }^{8}$ We believe our clinical appreciation of vital public health issues strengthens our advocacy.

When we ask doctors for help, the usual response is "I don't have time but I agree with your cause". To these colleagues we say, "Our work is funded almost totally on membership fees, so by joining you are helping". You can join here: http://dea.org.au/join.

Acknowledgements: We acknowledge the work of longstanding members of the DEA's Scientific Advisory Committee, the help of the late Tony McMichael and of Fiona Stanley and Peter Doherty, and the contributions of Sarah Morton, Grant Blashki, Colin Butler and John Stokes in the DEA's early days, as well as Michael Kidd and Kingsley Faulkner, subsequent Chairs of DEA.

Competing interests: No relevant disclosures.

Pronenance: Commissioned; not externally peer reviewed.

1 Doctors for the Environment Australia. Our vision. Vision statement. http://dea.org.au/about/our_vision (accessed Nov 2014).

2 Shearman D. Tony McMichael, his contribution to DEA and an appreciation of his life. Doctors for the Environment Australia. http://dea.org.au/news/ article/tony-mcmichael-his-contribution-to-dea-and-an-appreciation-ofhis-life (accessed Nov 2014).

3 Castleden WM, Shearman D, Crisp G, Finch P. The mining and burning of coal: effects on health and the environment. Med J Aust 2011; 195: 333-335.

4 Doctors for the Environment Australia. Coal is a major health issue like smoking. http://dea.org.au/news/article/coal-is-a-major-health-issuelike-smoking (accessed Nov 2014).

5 Hughes L, McMichael T. The critical decade: climate change and health. Canberra: Climate Commission Secretariat (Department of Climate Change and Energy Efficiency), 2011. http://www.climatecouncil.org.au/uploads/lb b6887d6f8cacd5d844fc30b0857931.pdf (accessed Nov 2013).

6 Shearman D. Time and tide wait for no man. BMJ 2002; 325: 1466-1468.

7 Shearman D. The climate "tide" is still rising. BMJ Blogs 2013; 25 Mar. http://blogs.bmj.com/bmj/2013/03/25/david-shearman-the-climatetide-is-still-rising (accessed Nov 2014).

8 Doctors for the Environment Australia. DEA in a heartbeat: who, what and why. http://dea.org.au/resources/file/dea-in-a-heartbeat-who-what-andwhy (accessed Nov 2014). 